Włodzimierz GAŁĄZKA

IT UKSW Warszawa

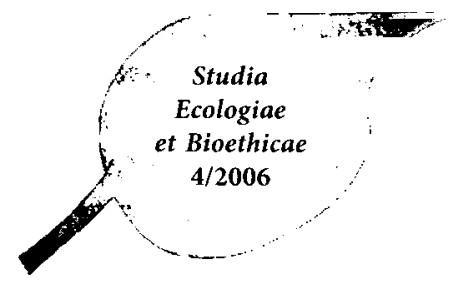

\title{
Rola katechety w rozwoju duchowym wychowanka
}

Współczesny świat, w którym żyjemy dostarcza nam obrazu wymiany pokoleniowej. Jedni z nas opuszczają go w nadziei, że dobrze wykorzystali darowany im czas, inni zaś przez swoje narodzenie wkraczają w codzienność tych, którzy tworzą daną rzeczywistość.

W dzisiejszej jednak dobie, szczególnie młody człowiek, który w tej rzeczywistości się znalazł na skutek powyżej wymiany narażony jest na szereg zagrożeń. Nie chodzi tylko o: nędze, glód, choroby, przemoc czy wojny ${ }^{1}$. Lecz o to wszystko, co może zagrozić jego jakąkolwiek sferę życia. Może być to np. błędna postawa wobec własnego ciała, która przejawia się w sprowadzeniu swojego człowieczeństwa jedynie do zaspokajania potrzeb cielesnych. Prowadzi to niestety zazwyczaj do wkroczenia w świat zagrożeń i patologii, a w konsekwencji do wewnętrznej walki. ${ }^{2}$

Odnosząc się do sfery psychologicznej największym zagrożeniem jest oszukiwanie samego siebie. Bywa, że młody człowiek używa własnej inteligencji nie po to, by szukać Boga, obiektywnej prawdy o sobie, lecz po to by znaleźć się w świecie fikcji i iluzji. Na skutek, czego tak postępująca osoba skłonna jest do manipulowania własnym myśleniem, tylko dla tego by naiwnie usprawiedliwiać popełnione przez siebie błędy. Jeżeli taka postawa dotyczyć będzie w sposób ewidentny sfery emocjonalnej, niewykluczone jest zagrożenie ucieczki chociażby w świat nałogów, gdyż jest to jeden ze sposobów zapomnienia tego, co niepokoi. ${ }^{3}$

Wychowawcy i pedagodzy zwracają coraz częściej uwagę, że branie środków uzależniających jest sygnałem problemów ucznia, z którymi sobie nie radzi. Przyczyny takiego stanu rzeczy Kościól dostrzega między innymi w: braku stabilizacji rodzin, napięciach międzyludzkich, wzroście bezrobocia, czy postępie techniki. Na skutek, czego korzeniem tego zła jest zanik wartości moralnych

Przemówienie Jana Pawla II w Radomiu, L'O. R. wyd. polskie, nr. spec. 9\1991, s. 41.

2 Por. Jan Pawe II, Projekt - czlowiek, W Drodze 10 (1986) 158, s. 91-98.

3 Przesłanie na IX Międzynarodowy Dzień Walki z Narkomanią i Nielegalnym Handlem Narkotykami, LO. R. wyd. polskie, n. 9\1966, s. 44-45 
$i$ duchowych ${ }^{4}$, trzeba zatem wszystko uczynić, aby pomóc młodemu człowiekowi na nowo odkryć własną godność. ${ }^{5}$ Bo jak mawiał Jan Paweł II: nie uczynienie tego prowadzi do zagrożenia jego godności i życia, co nie tylko wstrząsa od środka sercem Kościolem, dotyka samej istoty jego wiary w odkupieńcze wcielenie Syna Bożego, lecz także przynagla Kościól, by pelnit swą misję gloszenia Ewangelii życia całemu światu i wszelkiemu stworzeniu'.

I tu jest szczególne miejsce dla katechety, który przez systematyczną pracę na co dzień może i powinien uczestniczyć w procesach rozwojowych dzieci i młodzieży. Młody człowiek musi być przez kogoś autorytatywnego wprowadzony w misterium wiary, Boga i Kościoła. Przez kogoś kto ukaże mu misteryjny wymiar ludzkiego życia, jak również zachęci go w tym duchu do wszechstronnego i pełnego rozwoju. Bo tylko takie podejście do problemu pozwoli zachowując pełną integralność w zakresie katechezy oraz wychowania na równoległy rozwój trzech podstawowych władz człowieka: rozumu, woli i serca. ${ }^{7}$

Kiedy wychowanie zapewni harmonijny rozwój intelektu, woli i uczuciowości, wówczas w człowieku może wyłonić się osoba, która wyrazi się współdziałaniem tych trzech sil. Wówczas zadaniem katechety będzie formowanie wychowanka wedlug najlepszego wzorca, lecz tylko w taki sposób, który zapewni i umożliwi pełną jego oryginalność. Stanie się to wtedy, gdy nabędzie on (wychowawca) umiejętności towarzyszenia młodzieży, która oczekuje od niego jak pisze A. Offmański: zarówno wiedzy, jak i serca, zapału a także cierpliwości, roztropności oraz madrości $i^{8}$. Cechy te w czasie zmieniają się w konkretne postawy, które nie zmierzają jednak do gotowych rozwiązań, ale do wspólnego z młodymi ludźmi odkrywania prawdy. Katecheta musi jednak to swoją postawą proponować, aby umożliwiać im doświadczenie poszukiwania i odkrywania, które tak silnie określają ten okres życia. Równocześnie nie wolno zapomnieć o tym, że jeśli kształtowanie duchowe ma doprowadzać do zaistnienia i pogłębiania życia wewnętrznego to musi się oprzeć na takim sposobie widzenia i odniesienia cztowieka, który religijność uznaje za szczególny i zasadniczy wymiar osobowości ludzkiej. Jeśli człowiek nie zrozumie siebie jako istoty religijnej, będzie swoją religijność traktowat jako element folkloru - ważny, świadczacy o tożsamości kulturowej, ale nie zdolny do nadania życiu sensu ${ }^{9}$. Konkludując można opisać tę prawdę

4 Tamże

5 Tamże

6 Jan Pawe II, Spotkanie z przedstawicielami Urzędu ds. Szkolnictwa i Oświaty. Posługa nauczycieli religii, w: L'O. R. wyd. polskie, nr.2/1992, s. 12.

7 Por. I. Bertocco, Wychowanie integralne, w: Wychowanie chrześcijańskie, red. A. Solak, Tarnów 2002, s. 103 .

8 A. OCHмAŃski, Katecheza młodzieżowa na poziomie szkót ponadgimnazjalnych, w: Katechetyka szczególowa, red. J. Stala, Biblos, Tarnów 2003, s. 192.

9 K. OLBRyCht, Wychowanie religijne w świetle wspótczesnej sytuacji wychowanka, w: dzisiejszy aktualizowany. Stan aktulalny 
następująco. Jeżeli religijność będzie traktowana za nadrzędną wartość w życiu, to spełni ona swoją scalającą rolę w kształtowaniu młodego człowieka, czyniąc jednocześnie to, że ów młody postrzegany zostanie jako ktoś autentyczny, stając się jednocześnie znakiem Chrystusa w codzienności. By tak się mogło stać sam katecheta musi stać się najpierw świadkiem a potem kierownikiem duchowym dla młodego pokolenia.

\section{Świadectwo jako oddziaływanie na młodego człowieka}

Młodzi ludzie, z którym we współczesnej dobie przychodzi pracować katechetom to zróżnicowana kategoria osób, które ze względu na swój wiek, płeć, pochodzenie, temperament i osobiste doświadczenie. By dotrzeć do nich w sposób właściwy należy pominąć zgubną generalizację, która może doprowadzać do niezrozumienia nikogo, a odwołać się do świadectwa własnym życiem. Taka tylko postawa zapewnia osobowy kontakt $z$ podopiecznym. Wychowawca musi, zatem pamiętać, że młode pokolenie nie wychowują ani wartości, ani metody, lecz osoba wychowuje osobę. Katecheta musi być świadkiem, gdyż jak nauczał Jan Pawel II: tylko świadectwo życia ma decydujące znaczenie w sytuacji, gdy mlodzież poszukująca sensu życia spotyka się z tak wieloma różnymi odpowiedziami ${ }^{10}$.

Jednak by katecheta był świadkiem musi sam swoim życiem czynić widzialnym działającego Boga. Jest to możliwe przez postawę żywej i dojrzałej wiary, przygotowanej do tego, aby mogła jasno widzieć trudności oraz je przezwyciężać. Taka tylko wiara jest $\mathrm{w}$ stanie być owocna poprzez zachęcanie innych do postaw cechujących się sprawiedliwością i miłością. Dostrzec to można, kiedy zachodzą relacje braterskiej miłości między tymi wszystkimi, którzy współpracując w duchu Ewangelii stają się znakiem jedności. ${ }^{11}$

Taka relacja zachodzi wtedy, kiedy katecheta na wzór Chrystusa staje sługą Slowa. Będąc wówczas świadkiem chrześcijańskiego orędzia, pomaga innym w poszukiwaniu prawdy oraz w dochodzeniu do wyznaczonego przez Boga celu. I chociaż katechizujący jak mawiał ks. Edward Majcher: jest świadkiem odleglym o dwa tysiace lat od faktów zaistnialych na Palestyńskiej ziemi, to mimo to ma ukazywać wielka tajemnicę wiary, która trwa i jest równie aktualna dzisis ${ }^{\prime 2}$. Dzieje się to wówczas kiedy formujący posiada $w$ sobie miłoś́ pedagogiczną ${ }^{13}$. Określa się ją jako pragnienie obcowania $\mathrm{z}$ młodzieżą. Psychiczną postawę tej cechy stanowi prawdziwa życzliwość $w$ stosunku do wychowanków, chęć pomocy w ich pracy nad wzbogacaniem osobowości. Jeszcze istotniejszą jest umiejętność wywierania wpływu, nie tylko słowem, ale i ciepłym, życzliwym oddziaływaniem, przejawia-

\footnotetext{
10 JAN PAWEe II, Spotkanie z przedstawicielami Urzędu ds. Szkolnictwa i Oświaty. Posluga nauczycieli religii, w: L'O. R. wyd. polskie, nr.2/1992, s. 12.

11 KDK 21
} 
jącym się w uśmiechu, spojrzeniu i całej postawie. Dla tego Papież Polak pisał: jest w Ewangelicznym zapisie rozmowy Chrystusa z młodzieńcem jedno wyrażenie, które musimy sobie przyswoić, że „,ezus spojrzal na niego z miłością"14.

Miłość do młodych, to przede wszystkim świadomość tej odpowiedzialności i gotowość uczestnictwa w niej. Jest ona bezinteresowna, budząca w wychowankach zaufanie, a co najistotniejsze jest ona na tym etapie życia, który przechodzą niezbędna. Można powiedzieć, że cała postawa katechety w tej milości zdaje swój codzienny egzamin. A katecheta chcąc zdać go dobrze powinien odznaczać się wielką miłością do swoich podopiecznych. ${ }^{15}$

\section{Miłość do wychowanków pogłębiana przez kierownictwo duchowe}

Zazwyczaj, kiedy jest mowa o dzieciństwie i młodości, wówczas zwraca się szczególną uwagę na coś, co jest ze swej natury dynamiczne. Życie młodego człowieka może iść $w$ dwu kierunkach: do przodu i wstecz; może być postępem i regresją. Codzienność ludzka nigdy nie jest niezmienna, ciągle ewoluuje w jedną lub w drugą stronę. Chcąc wygrać przyszłość trzeba brać życie odpowiedzialnie, troszczyć się o nie, to znaczy prowadzić świadome pielęgnowanie nie tylko tego co jest na zewnątrz, lecz przede wszystkim co stanowi o wnętrzu istoty ludzkiej. I temu ma służyć kierownict wo duchowe. ${ }^{16}$

Nie można jednak tej formacji ludzkiej sprowadzać tylko do określonego zbioru pouczeń i zakazów. Ona, bowiem musi być jak mawiał Andre Louf towarzyszeniem duchowym, które jest niczym innym jak uprzywilejowana forma międzyludzkich relacji ${ }^{17}$.

W tym czasie bowiem dwie osoby będąc obok siebie powołane są do tego, aby przebyć wspólnie jakiś odcinek swojej życiowej drogi. Nie jest jednak wówczas najważniejszym przekazywanie wiedzy ani udzielanie dobrych rad. Najważniejsza jest iskra życia, którą jedna osoba ma przekazać drugiej. I nie ma to być jakiekolwiek życie, lecz życie samego Boga, światło i moc Jego Ducha. ${ }^{18}$

12 E. Majcher, Osobowość katechety, w: Katecheza w szkole, praca zbiorowa pod red. J. Śruciny, Wrocław 1992, s.150.

13 Tamże, s. 152.

14 Tamże

15 List Apostolski Ojca Świętego Jana Paweł II, do młodych całego świata z okazji Międzynarodowego Roku Młodych, w: A. Sieradzki, Stworzeni do milości. Rozmowy Jana Pawta Il z młodymi, Lomianki k. Warszawy 1991. s. 9-13.

16 Tamże

17 A. Louf, Towarzyszenie duchowe, Kraków 1991, s. 101.

18 Tamże 
Pomimo, że chodzi w tym wszystkim o wydarzenie duchowe to wcale nie jest powiedziane, że można oddzielić je od ludzkiej relacji łączącej dwie osoby. Przeciwnie. W żadnej ludzkiej relacji, nie ma takiego momentu, w którym by można sobie powiedzieć: do tego momentu nasza relacja jest naturalna a dalej duchowa. Taki podział jest absolutnie nie możliwy. Bowiem granica między tym, co naturalne i nadnaturalne nie jest wyraźnie widoczna w głębi naszej ludzkiej rzeczywistości. Cała sfera nadnaturalna jest jakoby wcielona w sferę naturalną. Życie Trzeciej Osoby Trójcy Przenajświętszej łączy się z ludzką psychiką. ${ }^{19}$

Można to wszystko zrozumieć i odnaleźć w swoim życiu, jeżeli jest ktoś, jak było to mówione powyżej, kto o takim stanie wie i umie to zastosować w codziennym życiu. Tym kimś jest osoba kierownika duchowego, który powinien pomagać młodemu człowiekowi uzyskać wewnętrzną pewność, zrównoważony osąd o sobie i o własnym życiu, optymizm sprzyjający osobistej inicjatywie. Wymaga to zdrowego sumienia pozbawionego egoistycznych zniewoleń i miłości własnej. Nie może bowiem mieć zdrowego sumienia ten, kto odrzuca przyjęcie światła z zewnątrz. Umocnienie sumienia przychodzi poprzez właściwą pracę $\mathrm{z}$ kierownikiem duchownym opartą na wierze i wzajemnym zaufaniu. Wiara dotyczyć powinna przekonania, że penitent oddawszy się do dyspozycji osoby, która ma mandat Kościola, znalazł się w rękach formującego Boga. ${ }^{20}$

Potrzeba kierownictwa duchowego wśród młodych jest na ogół przez nich akceptowana. Dotyczy to niestety w znacznej mierze tych, którzy przynależą do Kościoła. Chociaż młodzież, która mówi o sobie, że jest niewierząca, szuka osób dojrzałych duchowo, aby pomogli je w odkrywaniu i kształtowaniu własnej osobowości. Jest to nic innego jak naturalna potrzeba człowieka pytającego o sens swojego życia. ${ }^{21}$

Młodzież, która zdecydowała się na formację duchową ma wobec kierownika duchowego swoje oczekiwania. Dotyczą one autorytatywnego wskazywania drogi do Boga, rozumienia młodzieży, lojalności i szczerości, poszanowania wolności oraz osoby ludzkiej. Mówią oni: rola osoby prowadzacej nie jest $z$ pewnościa narzucanie własnego punktu widzenia ${ }^{22}$; kierownik, który śpieszy, ten nas zabija ${ }^{23}$.

Gdy chodzi o treść i ciągłość kierownictwa to pewna liczba młodych ludzi opowiada się za kierownictwem regularnym, które by było zgodne z wielkimi wzlotami i pragnieniami duszy młodzieńczej. Pragnie życiowych wskazań opartych o Ewangelię. Mówiąc o miejscu kierownictwa duchowego, życzenia mło-

\footnotetext{
19 Tamże

20 Por. J. Gigola, Kierownictwo duchowe, Kraków 1999, s. 126.

21 Por. P. Rostworowski, Kierownictwo duchowe, Kraków 1997, s. 57.

22 E. WERON, Kierownictwo duchowe, Warszawa 1983, s. 29.

23 Tamże
} 
dych są podzielone. Niektórzy chcą, aby kierownictwo duchowe dokonywało się w konfesjonale, inni poza nim..$^{24}$

Mówiąc o pragnieniach i oczekiwaniach związanych z kierownictwem duchowym trzeba zwrócić uwagę na jeszcze jeden ważny element: stopniowość w pielęgnowaniu swojego życia duchowego. Ks. Gogola przedstawia go za pomocą obrazu ukazującego kręcone schody. Twierdzi on, że wchodzenie po tych schodach na górę musi być odważne i systematyczne. Zaczynając od rzeczy łatwych i prostych, po to żeby potem przystąpić do bardziej poważnych i trudniejszych. Krocząc po takiej konstrukcji zawsze jest się blisko osi, symbolu wartości, w które się wierzy i siły zapewniającej zaangażowanie.

Kiedy te zależności będą zachowane, zawsze w większym czy mniejszym stopniu będzie można dostrzec pozytywny wpływ katechety na swojego podopiecznego. Bo jak wskazuje ludzkie doświadczenie postawa wychowawcy, który właściwie świadczy swoim życiem i jest przewodnikiem duchowym wywiera szczególny wpływ na formację wewnętrzną.

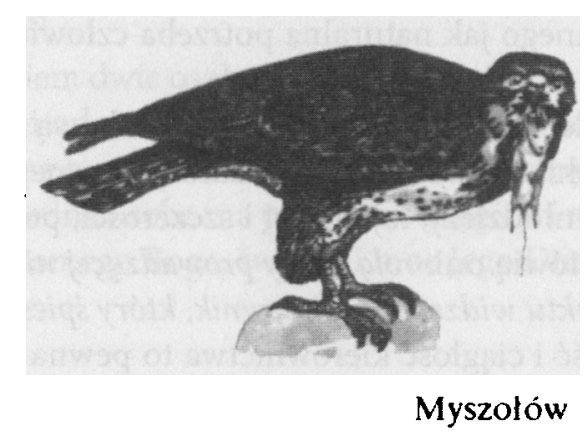

24 Por. P. Rostworowski, Kierownictwo duchowe, Kraków 1997, s. 34. 